\title{
STANDAR KAFA'AH DALAM PERKAWINAN MASYARAKAT MUSLIM YORDANIA, MAROKO, DAN PAKISTAN PADA ERA KONTEMPORER
}

\author{
Moh. Alfin Sulihkhodin, Muhammad Asadurrohman \\ UIN Sayyid Ali Rahmatullah Tulungagung, \\ UIN Maulana Malik Ibrahim Malang \\ Email: alfinarma@gmail.com,baadhlminkul@gmail.com
}

\begin{abstract}
ABSTRAK
Kafa'ah merupakan salah satu pertimbangan bagi seseorang saat hendak melakukan proses perkawinan. Secara umum konsep kafa'ah mengacu pada kesetaraan terkait dengan aspek agama, nasab, kecantikan/ketampanan dan materi akan tetapi, konsep sekufu lebih ditekankan pada permasalahan agama. Dalam perkembangannya konsep kafa'ah sebagaimana di negara Maroko, Yordania, serta Pakistan telah bergeser tidak hanya sekadar terpaku pada permasalahan materi, nasab, agama atau paras semata. Akan tetapi, dalam beberapa hal masih tetap berpegang pada pendapat ulama' madzhab. Kendati bukan sebagai sebuah keharusan bagi seorang calon mempelai, konsep kafa'ah dinilai memiliki sumbangsih bagi tercapainya keluarga yang sakinah, mawaddah, dan rahmah.
\end{abstract}

Kata Kunci: Perkawinan, Kafa'ah, Negara Muslim.

\section{ABSTRACT}

Kafa'ah is one of the considerations for someone when it comes to marriage. In general, the concept of kafa'ah refers to equality related to aspects of religion, nasab, beauty / good looks and material, however, the concept of sekufu is more emphasized on religious issues. It's development the concept of kafa'ah as in Morocco, Jordan, and Pakistan has shifted not only fixated on material, nasab, religion or physically problems. However, in some ways it still sticks to the views of ulama' madzhab. Although not as a necessity for a bride to be, the concept of kafa'ah is considered to have a contribution to the achievement of a family that is sakinah, mawaddah, and rahmah.

Keywords: Marriage, Kafa'ah, Moslem State. 


\section{A. PENDAHULUAN}

Salah satu dari sekian aspek penting sebelum dilaksanakannya sebuah proses perkawinan adalah terkait dengan pertimbangan kesepadanan atau kafa'ah di antara kedua calon mempelai. Hal ini dilakukan mengingat, kafa'ah merupakan salah satu dari sekian kunci penting untuk dapat mewujudkan kehidupan rumah tangga yang sakinah, mawaddah, dan rahmah.

Secara umum pertimbangan kafa' $a h$ adalah didasarkan pada kesepadanan dalam hal kepemilikan harta, kecantikan/ketampanan, nasab, dan pertimbangan pada kesamaan atas sebuah keyakinan (ad-din). Dalam pandangan ulama' fiqh klasik, kedudukan yang setara dalam urusan keagamaan dinilai menjadi hal yang paling utama. Sebab, apabila agama seseorang telah rusak, maka indikasinya adalah kerusakan pada sendi lainnya dalam kepribadian seorang calon mempelai.

Tak ubahnya dalam praktek perkawinan masyarakat muslim Malayu, Indonesia, maupun negara muslim lain yang menempatkan kriteria kufu' dalam bidang agama sebagai salah satu hal yang harus terpenuhi. Utamanya pada periode fiqh klasik, di mana culture religi yang masih sangat begitu dijunjung tinggi. ${ }^{1}$ Atau lebih mengedepankan pandangan ulama' madzhab, seperti halnya madzhab Syafi'iyyah di Indonesia, dan negara muslim di Asia Tenggara lainnya. ${ }^{2}$ Atau di negara Yordania serta Pakistan yang lebih cenderung pada pandangan ulama' madzhab Hanafi. Atau di Maroko yang mana lebih condong pada ketentuan Imam madzhab

\footnotetext{
${ }^{1}$ Komarudin Komarudin, "Hukum Keluarga di Tunisia dan Indonesia," Kordinat: Jurnal Komunikasi Antar Perguruan Tinggi Agama Islam $\begin{array}{lllll}\text { Vol. } & 18 & \text { No. } & 1 & \text { (2019): } \\ 197,\end{array}$ https://doi.org/10.15408/kordinat.v18i1.11481.

2 Mohammad Alfin Sulihkhodin, "Prosesi Khitbah di Indonesia Perspektif Local Wisdom dan Qaidah Fiqh," Bilancia: Jurnal Studi Ilmu Syariah Dan Hukum Vol. 14 No. 2 (2020): 385, https://doi.org/10.24239/blc.v14i2.553.
}

Maliki. Apabila tidak terpenuhi, bisa saja prosesi khitbah yang mengarah pada pelaksanaan perkawinan dibatalkan dan tidak dapat dilanjutkan kembali. ${ }^{3}$

Akan tetapi, paradigma fiqh klasik menyangkut bidang hukum keluarga dalam masyarakat muslim di dunia perlahan mulai mengalami pergeseran dan perubahan. Perubahan karena pengaruh perkembangan teknologi, kemajuan zaman dan ilmu pengetahuan, perlahan mulai menjadikan perubahan culture yang berbeda dalam suatu masyarakat. Ada mereka yang tetap teguh dan menganut pandangan fiqh klasik, ada mereka yang berusaha untuk menyelaraskan dan memadukan di antara keduanya, atau bahkan adapula mereka yang secara keseluruhan merubah pandangan klasik menjadi fiqh modern. Karena dinilai lebih mampu hidup dan dapat menjawab kebutuhan serta persoalan baru di tengahtengah masyarakat secara luas. ${ }^{4}$

Selanjutnya pembaruan dalam bidang hukum keluarga Islam sendiri memang cukup tampak menarik dalam beberapa kategori di pelbagai negara muslim yang terdapat di dunia. Untuk yang pertama, seperti halnya negara di wilayah Timur Tengah, Arab Saudi, negara-negara ini memilih untuk tetap berpegang pada ketentuan hukum keluarga Islam klasik, dengan berpedoman pada ketentuan nash, atau pendapat ulama fiqh pada masanya. Artinya, produk hukum yang telah ada pada zaman dahulu tetap berupaya untuk dipertahankan dan tidak dirubah sedikitpun. ${ }^{5}$

Dan untuk yang kedua, sebagaimana beberapa negara yang terdapat di wilayah

3 Koko Komarudin, "Hakikat Keluarga Islam," Al-Ihkam: Jurnal Hukum Keluarga Vol. 12 No. 2 (2020): 129.

4 Imam Mustofa, "Ijtihad Kontemporer Sebagai Upaya Pembaruan Hukum Keluarga di Indonesia," Al-Manahij: Jurnal Kajian Hukum Islam Vol. 7 No. 2: https://doi.org/10.24090/mnh.v7i2.565.

5 Hamsah Hudafi, "Pembentukan Keluarga Sakinah Mawaddah Warahmah Menurut UndangUndang Nomor 1 Tahun 1974 dan Kompilasi Hukum Islam," Al Hurriyah: Jurnal Hukum Islam Vol. 5 No. $2 \quad$ (2020): 175, https://doi.org/10.30983/alhurriyah.v5i2.3647. 
benua Eropa, Turki sebagai salah satunya, produk hukum keluarga di negara ini telah dilakukan upaya perubahan. Dari yang bersifat fiqh klasik-religiusitik, berubah menjadi hukum yang bersifat sekuler. Di mana unsur agama, kepercayaan, harus dipisahkan dari unsur administrasi negara. Atau kategori yang ketiga, sebagaimana halnya negara Indonesia, Tunisia, Pakistan, Maroko, Yordania, Mesir, dan beberapa negara lain, yang berupaya untuk melakukan perubahan hukum keluarga Islam klasik yang ada sebelumnya, dengan mengkolaborasikan pada hukum yang bersifat sekuleristik. ${ }^{6}$

Sebagai agama yang mayoritas dianut oleh masyarakat Pakistan, Maroko, serta Yordania, Islam berkembang sebagai sebuah landasan idiil yang dijadikan sebagai jalan dan pedoman hidup yang utama. Tak ubahnya mengenai konsep (standar) kafa'ah di antara kedua calon mempelai yang hendak melangsungkan perkawinan mereka. Kendati bukan bersifat sebagai sebuah keharusan dalam pernikahan, akan tetapi guna membina rumahtangga yang baik, harmonis, setidaknya akan lebih terjamin apabila masing-masing calon pengantin menentukan pilihan pasangan hidupnya dengan menerapkan konsep keselarasan, atau $k u f u^{\prime}$ itu sendiri.

Melihat akan hal itu, apakah kiranya di negara-negara muslim tersebut juga menerapkan konsep yang sama sebagaimana di negara Indonesia, atau justru sebaliknya. Berangkat dari latar belakang inilah kiranya menurut penulis penting untuk mengkaji, serta memperdalam pembahasan berkaitan dengan konsep $k a f a a^{\prime} h$ di negara muslim Yordania, Maroko, serta Pakistan. Utamanya realitas yang ada pada era kontemporer ini.

\section{B. METODOLOGI PENELITIAN}

\footnotetext{
6 Muhammad Nur Hasan Latief, "Pembaharuan Hukum Keluarga serta Dampaknya Terhadap Pembatasan Usia Minimal Kawin dan Peningkatan Status Wanita," Jurnal Hukum Novelty $\begin{array}{lllll}\text { Vol. } & 7 & \text { No. } & 2 & \text { (2016): } \\ 198 \text {, }\end{array}$ https://doi.org/10.26555/novelty.v7i2.a5467.
}

Penelitian terkait dengan hal ini penulis lakukan dengan menggunakan pendekatan penelitian yang bersifat kualitatif. Pengambilan data akan dilakukan melalui metode library research. Yakni, melalui penggalian data pada buku-buku, jurnal-jurnal ilmiah, majalah, artikel, aturan perundang-undangan terkait hukum keluarga atau sumber bacaan lainnya sebagai pendukung. Salah satu tujuan utamanya adalah guna memudahkan peneliti pada proses penggalian dan analisis data berkaitan dengan standar kafa'ah dalam konteks perkawinan masyarakat muslim di negara Yordania, Maroko, serta Pakistan. Di mana berkaitan dengan hasil penelitian nantinya dapat dijadikan sebagai unsur pembanding atau pembaruan dalam materi hukum keluarga yang terdapat di negara Indonesia sendiri, secara khusus terkait dengan kriteria sekufu dalam perkawinan masyarakat muslim modern. ${ }^{7}$

\section{HASIL DAN PEMBAHASAN}

\section{Konsep Umum Kafa'ah Dalam Perkawinan}

Pernikahan dalam ajaran Islam adalah bersinggungan erat dengan bidang ibadah. Juga aspek muamalah di antara sesama manusia sebagai makhluk sosial, yang tak dapat lepas daripada aturan hukum di suatu negara. Pernikahan di mana telah memenuhi semua syarat serta rukun utama daripadanya telah dianggap sah secara ketentuan agama. Akan tetapi, apabila syarat secara administrasi negara juga dapat dipenuhi, maka jaminan agama dan hukum yang didapat oleh seseorang akan lebih terjamin. ${ }^{8}$

"Wahai para pemuda, barangsiapa di antara kamu sekalian telah mampu dan

7 Suharsimi Arikunto, Prosedur Penelitian: Suatu Pendekatan Penelitian, (Jakarta: Rineka Cipta, 2014), 32.

${ }^{8}$ Komarudin, "Hukum Keluarga di Tunisia dan Indonesia...", 197. 
memiliki bekal hidup, maka menikahlah. Karena sesungguhnya menikah akan lebih mampu untuk menjaga pandangan serta kemaluanmu. Barangsiapa yang belum mampu melaksanakannya, maka hendaklah berpuasa, karena dengan berpuasa akan menjadi penghalang nafsu." (HR. Muttafaqun 'Alaih) ${ }^{9}$

Sebagai sunnah Nabi Muhammad SAW yang mulia, jika dilihat dari salah satu tujuan utama pernikahan yakni, guna terwujudnya keluarga yang sakinah, mawaddah, dan rahmah, oleh karenanya aspek kehati-hatian dalam menentukan calon pendamping hidup menjadi unsur yang sangat penting untuk senantiasa diperhatikan. Salah satu pertimbangan penting dalam memilih pasangan itu sendiri adalah melalui proses kafa' $a h^{10}{ }^{10}$

Ukuran dalam suatu kriteria menilai seseorang dianggap sekufu juga bersifat sangat relatif. Akan tetapi dalam konteks fiqh klasik dapat diartikan dengan sekufunya seseorang dalam bidang keagamaan (adDin), harta kekayaan masing-masing calon mempelai (al-Mal), Permasalahan menyangkut asal-usul (nasab) seseorang, atau pada permasalahan kecantikan paras dan ketampanan seseorang. Dan penilaian untuk lebih memilih masalah keagamaan, adalah lebih diutamakan. ${ }^{11}$

Kafa'ah memang menjadi suatu hal yang sangat penting dalam permulaan perkawinan. Setidaknya, apabila kesepadanan di antara kedua calon mempelai telah terpenuhi, maka jalan untuk lebih dekat menuju pada kebahagiaan dalam sebuah ikatan perkawinan akan terasa lebih dekat adanya. Serta kemungkinan terhindar dari suatu pertengkaran atau percekcokan dalam rumah tangga akan semakin lebih terjamin. $^{12}$

${ }^{9}$ Al-Shan'any, Subul al-Salam, Juz 3, (Kairo: Dar Ihya' al-Turats al-Araby, 1980 M), 109.

10 Sulihkhodin, "Prosesi Khitbah Di Indonesia...", 391.

11 Sulihkhodin, "Prosesi Khitbah Di Indonesia...", 391.

${ }_{12}$ Mustofa, "Ijtihad Kontemporer Sebagai Upaya Pembaruan...”, 15.
Permasalahan perkawinan di dalam ajaran Islam diatur dengan sedetail mungkin. Baik dari syarat, maupun semua rukun dalam perkawinan yang harus dipenuhi. Tak terkecuali, mengenai pertimbangan untuk memilih calon suami/isteri. Karena selain berupaya untuk dapat mewujudkan rumahtangga yang bahagia, penuh dengan rahmat dan kedamaian, perkawinan juga diharapkan hanya terjadi sekali seumur hidup. Dengannya, masalah kafa'ah menjadi salah satu dari sekian unsur penting yang harus senantiasa diupayakan. ${ }^{13}$

Kafa'ah memang tidak menjadi sebuah keharusan dalam suatu pernikahan. Akan tetapi, dalam beberapa sunnah Nabi SAW telah diberikan petunjuk-petunjuk tertentu dalam memilih seorang pasangan. Di antaranya: 1. Mereka yang taat dalam hal beragama dan menjalankan seluruh kewajiban yang dipikulnya, 2. Mereka yang berasal dari keturunan yang subur, dalam arti lain bukan berasal dari keturunan seseorang yang mandul, 3. Mereka yang masih perawan atau belum pernah menikah dan memiliki keturunan. ${ }^{14}$

Sebagaimana dalam sebuah hadits, "Dari Jabir, nabi SAW telah bersabda: "Sesungguhnya perempuan itu dinikahi karena agamanya, harta, dan kecantikannya, maka pilihlah yang beragama." (HR. Muslim \& Tirmidzi) Hadits ini secara khusus menyinggung terkait dengan kriteria seorang calon isteri, akan tetapi dalam makna lain juga dapat dipahami bahwa syarat tersebut berlaku pula bagi seorang calon suami. Muslim yang baik untuk mereka muslimah yang baik, mukmin yang baik untuk mereka mukminah yang baik. Demikian pula sebaliknya.

Pada dasarnya kedudukan, hakkewajiban seseorang adalah sama. Akan tetapi, tidak dapat dipungkiri bahwa kualitas agama, serta keimanan daripada seseorang menjadi sebuah jaminan yang utama.

13 Ahmad Rofiq, Hukum Perdata Islam di Indonesia Edisi Revisi, Cet. 2, (Jakarta: PT. Raja Grafindo Persada, 2015), 54.

14 Beni Ahmad Saebani, Fiqih Munakahat 1, (Bandung: CV Pustaka Setia, 2013), 152. 
Bilamana agama dan keimanan seseorang baik, dapat dipastikan itu semua akan berpengaruh pada sisi kehidupan lainnya. Utamanya dalam permasalahan pernikahan atau rumahtangga.

\section{D.STANDAR KAFA'AH DI NEGARA YORDANIA}

Sebagai salah satu dari sekian negara muslim yang terdapat di dunia, Yordania termasuk sebagai salah satu negara yang berupaya untuk melakukan pembaruan hukum keluarga Islam. Hal tersebut dapat dilihat dari produk hukum yang menyangkut permasalahan bidang hukum keluarga di dalamnya. ${ }^{15}$ Apabila dilihat secara umum, landasan hukum utama yang diterapkan sebagai dasar untuk menyelesaikan permasalahan dalam kaitannya dengan hukum keluarga adalah dengan lebih banyak merujuk pada pendapat ulama' fiqh klasik. Sebagai salah satunya pandangan ulama' madzhab Hanafi yang mendapatkan ruang tersendiri di kalangan masyarakat muslim Yordania.

Pandangan hukum ulama' Hanafiyah cukup memiliki pengaruh yang besar di negara ini. Di mana pada sekitar tahun 1917 Yordania memberlakukan aturan hukum keluarga "The Ottoman Law of Family Rights" sebelum lahirnya aturan UndangUndang Nomor 92 pada kisaran tahun 1951. Adapun sebelum lahirnya ketentuan hukum tersebut, Yordania juga pernah menerapkan aturan atau yang lebih dikenal dengan "Qanun al-Huquq al-A'ilah al-Urduniah" Nomor 26 di kisaran tahun 1947. Oleh karena itu, dengan lahirnya aturan hukum Nomor 92 Tahun 1951 ini maka, semua aturan terdahulu terkait dengan bidang hukum keluarga telah dilakukan revisi dan diganti. ${ }^{16}$

Melihat ketentuan isi UndangUndang Nomor 92 yang dibuat pada Tahun 1951 ini, mencakup dari sekitar 132

\footnotetext{
15 Komarudin, "Hukum Keluarga Di Tunisia...", 198.

16 Aulia Muthiah, Hukum Islam Dinamika Seputar Hukum Keluarga, (Yogyakarta: Pustaka Baru Press, 2017), 47.
}

ketentuan pasal di dalamnya. Yang kemudian dibagi menjadi 16 bab utama. Sekilas isi daripaada ketentuan UndangUndang ini cukup memiliki kemiripan dengan ketentuan aturan hukum Turki Tahun 1917. Secara sistematika kepenulisan, maupun unsur isi di dalamnya memiliki corak yang hampir sama. ${ }^{17}$ Undang-Undang ini sendiri kemudian diperbarui lagi dengan lahir dan dibuatnya Undang-Undang yang lebih dinilai komprehensif dengan lahirnya aturan hukum "Law of Personal Status" atau yang secara umum lebih banyak dikenal dengan sebutan "Qanun al-Ahwal alSyakhshiyyah" Nomor 61 Tahun 1976. Sebelum adanya UU ini, konsep dasar, pandangan hukum dari kalangan madzhab Hanafi dijadikan sebagai dasar rujukan utama. ${ }^{18}$

Perombakan mendasar yang dilakukan dalam proses pembaruan aturan hukum keluarga di negara ini, secara utama menyangkut permasalahan batasan usia minimal diperbolehkannya seseorang untuk menikah. Kemudian permasalahan administrasi dalam perkawinan, mulai dari proses pencatatan perkawinan, perceraian, ataupun unsur administratif lainnya. Pemberlakuan keharusan talaq di hadapan hakim Pengadilan Agama setempat, permasalahan wali dalam pernikahan, serta menyangkut permasalahan janji di dalam perkawinan. ${ }^{19}$

Agama Islam sebagai mayoritas di negara ini, memiliki pengaruh yang besar bagi corak kebudayaan masyarakat Yordania, maupun dalam tata pemerintahannya. Sebagai penganut muslim sejati, tak ayal apabila produk hukum yang ada memiliki nuansa religi dan ciri khas tersendiri. Sebagaimana negara muslim

\footnotetext{
${ }^{17}$ Latief, "Pembaharuan Hukum Keluarga...", 199.

18 Abdul Halim Barkatullah dan Teguh Prasetyo, Hukum Islam Menjawab Tantangan Zaman yang Terus Berkembang, (Yogyakarta: Pustaka Pelajar, 2006), 122.

${ }^{19}$ Khoiruddin Nasution, "Metode Pembaruan Hukum Keluarga Islam Kontemporer," Unisia 30, no. 66 (October 25, 2007): 335, https://doi.org/10.20885/unisia.vol30.iss66.art1.
} 
lainnya di wilayah Timur Tengah, negara ini menempatkan nilai religius keIslaman sebagai salah satu sumber daripada hukum negara. ${ }^{20}$

Sekali lagi, nuansa atau corak hukum dari pengaruh pandangan ulama' Hanafi cukup terasa sekali di negara ini. Mengingat, dahulu sebelum berdaulat serta mendeklarasikan sebagai negara sendiri yang mandiri, terlepas dari pengaruh kekuasaan negara lain, dahulu Yordania termasuk sebagai salah satu negara yang berada di bawah kekuasaan kerajaan Turki Utsmani. ${ }^{21}$

Sedikit menelisik konsep kafa'ah di negara sebagai penganut mayoritas muslim yang ternisbatkan dalam ketentuan fiqh madzhab Hanafi, sebagai hal yang utama patokan atau kriteria kafa'ah adalah menyangkut 5 kriteria dasar. Di mana sekufu dinilai atas dasar, keagamaan, keturunan, hurriyah, harta kekayaan kedua calon mempelai, serta tingkatan atau bidang pekerjaan dari seseorang. Serta tidak menutup kemungkinan, di mana kriteria sekufu dalam konteks ini dinisbatkan pada sekufunya suku atau sebangsa, setanah air, di antara kedua calon mempelai. ${ }^{22}$

Tak ubahnya Rasulullah yang berasal dari kalangan bani Qurais, kemudian bangsa Arab dengan sesama masyarakat muslim Arab. Muslim Asia dengan sesama muslim di wilayah Asia dan permisalan lainnya. Akan tetapi, dalam konteks modern semacam ini tidak serta merta dapat diartikan demikian. Karena sejatinya, masyarakat muslim dengan sesama muslim lainnya adalah sejajar, sebanding. Terkecuali, dalam permasalahan yang

${ }^{20}$ Khoiruddin Nasution, "Metode Pembaruan Hukum Keluarga Islam Kontemporer," Unisia 30, no. 66 (October 25, 2007): 335, https://doi.org/10.20885/unisia.vol30.iss66.art1.

${ }^{21}$ Muslim Secular Democracy, Muslim Secular Democracy, 2013, https://doi.org/10.1057/9781137282057.

22 Sulihkhodin, "Prosesi Khitbah Di Indonesia...", 393. menyangkut urusan bathiniyah, keimanan, ketaqwaan seseorang pada Rabbnya. ${ }^{23}$

Dalam pandangan madzhab Hanafiyah sejatinya seorang laki-laki yang berasal dari clan Arab adalah sekufu dengan wanita yang hanya berasal dari bangsa Arab pula. Begitu pula sebaliknya, seorang wanita Arab adalah sekufu dengan laki-laki yang sama-sama berasal dari tanah Arab. Akan tetapi, apabila seorang laki-laki shalih dan memiliki tingkat intelektual yang begitu tinggi, walaupun mereka tidak berasal dari suku Arab maka mereka tetap dianggap sebanding dengan wanita Arab. Mengingat, derajat seseorang yang berilmu memiliki kedudukan yang lebih tinggi daripada sekadar dibandingkan dengan nasab, atau harta kekayaan yang seseorang miliki. ${ }^{24}$

Masalah nasab memang memiliki kedudukan yang penting bagi seseorang. Baik atau buruknya sifat seseorang sedikitbanyak dapat dilihat dari mana asal-usul keturunan, kendati dalam era kontemporer ini tak selamanya dapat dijadikan sebuah jaminan utama. Ada mereka yang hanya berasal dari kelas sosial yang rendah akan tetapi justru memiliki sikap dan kepribadian yang baik. Sebaliknya, mereka yang berasal dari keturunan seorang yang baik justru bertindak kebalikannya.

Tak ubahnya di negara Indonesia, bahwa masalah kufu' di Yordania juga dilihat dari sifat keagamaan atau keshalihan seorang calon mempelai. Artinya, seseorang yang dianggap sebagai muslim adalah mereka yang memiliki budi pekerti yang baik dan sifat ketaqwaan pada Rabbnya. Karena pembeda yang utama di antara seorang hamba ialah tentang keimanan dan ketaqwaan pada Tuhannya. Bukan terletak pada seberapa banyak harta kekayaan yang dimiliki. ${ }^{25}$

23 Komarudin, "Hukum Keluarga D Tunisia...", 197.

${ }^{24}$ Khoiruddin Nasution, "Metode Pembaruan Hukum Keluarga...", 334.

${ }^{25}$ Nurhadi Nurhadi, "Undang-Undang No. 1 Tahun 1974 Tentang Pernikahan (Perkawinan) Di Tinjau Dari Maqashid Syariah," UIR Law Review Vol. 2 No. 2 (2018): 125 , https://doi.org/10.25299/uirlrev.2018.vol2(02).1841. 
Perihal usia perkawinan, dalam ketentuan UU di negara ini syarat bagi seorang laki-laki dan perempuan untuk dapat melangsungkan pernikahan mereka apabila telah mencapai usia 16 dan 15 tahun. Sedangkan di negara Indonesia usia perkawinan telah diperbarui menjadi 19 tahun sama sebagaimana dalam ketentuan UU Perkawinan. Usia ini di negara Yordania telah dianggap sebagai usia dewasa. ${ }^{26}$

Artinya bilamana seseorang yang telah mencapai usia tersebut dan hendak melangsungkan perkawinan, sedangkan di satu sisi masih terkendala restu dari seorang wali maka mereka dapat mengajukan izin di pengadilan setempat. Selama calon suaminya dianggap sekufu, maka tanpa seizin daripada kedua orang tua dapat digantikan dengan persetujuan dari pengadilan.

Sebagaimana ketentuan yang termakhtub dalam Pasal 21 Regulasi Perkawinan di negara ini, pada dasarnya pihak keluarga dari seorang perempuan, utamanya seorang wali, apabila dalam perkawinan tersebut diketahui bahwa calon mempelai laki-laki tidak sekufu, sedangkan dalam perjanjian sebelumnya disyaratkan adanya kesebandingan, maka apabila ditemui ketidaksesuaian pada saat akad pernikahan, mereka dapat melakukan pembatalan atau dikenal dengan istilah fasakh. $^{27}$

Bilamana benar-benar diketahui bahwa seorang anak (baik gadis atau janda) yang menikahkan dirinya pada laki-laki pilihannya, dan ternyata tidak sekufu, maka seorang wali sekali lagi memiliki hak untuk

${ }^{26}$ Nurhadi Nurhadi, "Undang-Undang No. 1 Tahun 1974 Tentang Pernikahan (Perkawinan) Di Tinjau Dari Maqashid Syariah," UIR Law Review $\begin{array}{lllll}\text { Vol. } 2 & 2 & \text { No. } & 2 & \text { (2018): } \\ & \text { 125, }\end{array}$ https://doi.org/10.25299/uirlrev.2018.vol2(02).1841

27 Lihat Regulasi tentang Perkawinan di negara Yordania mengenai permasalahan sekufu dalam pernikahan, serta alasan-alasan apa saja yang dapat dijadikan sebagai proses pengajuan fasakh apabila diketemui ketidaksesuaian dalam perjanjian perkawinan. Sebagaimana termakhtub dalam "Qanun al-Ahwal al-Syakhshiyyah” Nomor 61 Tahun 1976. dapat melangsungkan pembatalan perkawinan tersebut.

"Penilaian terhadap seorang calon mempelai (suami/isteri) adalah terletak pada kata kufu' bukan pada besarnya mahar, karena meskipun maharnya bukan mahar mitsil akan tetapi masih sekufu, wali tidak dapat mengajukan fasakh nikah tersebut" (Ketentuan Pasal 22).

"Seorang hakim akan mengabulkan permohonan fasakh tersebut apabila si isteri tidak dalam keadaan sedang hamil" (Ketentuan Pasal 23). ${ }^{28}$

Perlu untuk digaris bawahi bahwa kriteria kafa'ah sejatinya adalah terletak pada sifat atau kemampuan seorang laki-laki secara khususnya untuk memberikan mahar secara tunai pada saat akad pernikahan dilangsungkan dan kemampuan dalam menjamin serta memenuhi kebutuhan nafkah lahir dan bathin keseharian seorang isteri dan anak-anak mereka. ${ }^{29}$ Kendati kekayaan dalam hal ini bukan menjadi sebuah prioritas utama, akan tetapi ia juga memiliki kedudukan yang penting apabila dibandingkan dengan kriteria sekufu lainnya. Bilamana kebutuhan sehari-hari dalam rumah tangga dapat terpenuhi dengan baik, keharmonisan, kerukunan, dan kebahagiaan dalam lingkup rumah tangga sedikit-banyak juga akan ikut serta memengaruhi dan kemungkinan besar akan dapat tercapai.

Sebagai negara yang mayoritas penduduknya bermadzhab Hanafi, kendati pada dasarnya dalam pandangan ini kedudukan seorang wali pada saat akad perkawinan dilangsungkan bukan menjadi sebuah keharusan, akan tetapi dalam regulasi perkawinan yang ada hak-hak

${ }^{28}$ Kendati seorang anak memiliki legalitas untuk dapat menikahkan dirinya sendiri dengan seseorang yang dicintai dan dipilihnya sendiri, akan tetapi hak kewalian orang tua tidak serta merta lepas begitu saja. Mereka juga masih tetap mempunyai hak untuk mengajukan pembatalan (fasakh).

${ }^{29}$ Muhammad Ridwansyah, "Keadilan Gender Dalam Rancangan Qanun Hukum Keluarga," Jurnal Hukum Samudra Keadilan Vol. 14 No. 2 (2019): 17. 
mereka sebagai seorang wali tetap diakui dan dijunjung tinggi. ${ }^{30}$

Kendati seorang wanita yang telah mencapai usia dewasa atau telah dapat melangsungkan perkawinannya sendiri, secara khusus pada saat telah mencapai usia 18 tahun, akan tetapi keberadaan dan kewenangan seorang wali tetap pada fungsi utamanya. Yakni, sebagai pihak yang memiliki kewajiban untuk mendidik, merawat, serta mengawasi segala tindakan hukum, secara khusus dalam lingkup keperdataan atas anak-anak mereka. Hal ini juga dipandang sebagai sebuah bentuk kemajuan dalam pembaruan bidang hukum keluarga Islam. ${ }^{31}$

\section{E. STANDAR KAFA'AH DI NEGARA MAROKO}

Maroko sebagai salah satu negara dengan penduduk muslim sebagai mayoritas, tentu sudah tidak begitu asing dan telah cukup banyak didengar oleh negara sesama muslim lainnya. Maroko merupakan sebuah negara yang berbentuk kesultanan Islam, dengan jumlah penduduknya mencapai kurang lebih hampir 32 juta jiwa, jumlah yang tidak dapat dibilang sedikit. Hampir semua warga negaranya beragama Islam, tak kurang dari $99 \%$. Sunni adalah sebagai salah satu madzhab yang banyak dianut di negara ini. ${ }^{32}$

Bahasa Arab menjadi bahasa yang resmi digunakan di negara ini. Adapun dengan bahasa asing yang cukup populer adalah bahasa Prancis. Penduduk muslim di negara ini juga dijuluki sebagai mayoritas muslim yang beraliran Sunni.

Terkait proses pembaruan produk hukum keluarga, nampak adanya sebuah isi perundangan yang bersifat adil dan menempatkan kesetaraan gender antara seorang laki-laki dan perempuan. Secara khusus terkait dengan pembagian kedudukan

\footnotetext{
${ }^{30}$ Khoiruddin Nasution, "Metode Pembaruan Hukum Keluarga...", 336.

${ }^{31}$ Khoiruddin Nasution, "Metode Pembaruan Hukum Keluarga...", 336

K2 Komarudin, "Hukum Keluarga Di Tunisia...", 198.
}

dan peran seorang suami atau isteri. Hal tersebut dapat dilihat dari unsur muatan regulasi perkawinan melalui "Mudawanah" nya.

Kisaran tahun 2004, sebagai sebuah upaya perwujudan kesetaraan gender di dalam tata kehidupan masyarakat melalui lini terkecil keluarga, dengan berhasil ditorehkannya "Mudawanah al-Usrah" atau UU tentang Hukum Keluarga. Keberlakuan UU yang baru ini sekaligus menggantikan kedudukan regulasi sebelumnya yang kurang lebih telah diberlakukan selama kurang lebih 50 tahun sebelumnya. ${ }^{33}$

Adapun beberapa poin penting dalam hal pembaruan hukum keluarga Islam di negara Maroko adalah terkait dengan:

1. Tanggung jawab terhadap keutuhan dan keberlangsungan suatu keluarga menjadi tanggung jawab bersama seorang suami dan isteri. Sebelumnya, regulasi yang ada hanya menekankan kedudukan tersebut pada seorang suami. Mengingat, statusnya adalah sebagai kepala rumah tangga. Akan tetapi, setelah terjadinya proses pembaruan regulasi, kedudukan mereka menjadi lebih seimbang dan tidak ada yang dinilai lebih dominan.

2. Bilamana seorang wanita yang telah sampai pada usia menikah dan dewasa, mereka diberikan kewenangan tersendiri untuk menentukan sendiri calon pasangan hidupnya tanpa adanya sebuah unsur paksaan atau kekangan dari seorang wali. Apabila mereka dipaksa untuk menikah dengan seseorang yang sama sekali tidak dicintainya, maka mereka memiliki hak prerogatif untuk menolaknya. Dan tanpa adanya izin seorang walipun, seorang perempuan dapat menikahkan dirinya sendiri.

${ }^{33}$ Khoiruddin Nasution, "Metode Pembaruan Hukum Keluarga...", 337. 
3. Batas usia seseorang boleh untuk melangsungkan perkawinan adalah sama 18 tahun. Jika dibandingkan dengan pembaruan regulasi di Indonesia hanya selisih sekitar 1 tahun saja. Usia ini kiranya juga dinilai sebagai salah satu upaya untuk menekan terjadinya pernikahan usia dini.

4. Perkawinan poligami juga memiliki persyaratan yang amat sangat ketat, dimana merubah aturan yang telah ada sebelumnya dimana masih cukup membebaskan terjadinya praktek perkawinan poligami di negara ini. ${ }^{34}$

Capaian prestasi yang besar itu, sudah pasti diawali dengan adanya sebuah perjalanan sejarah yang cukup panjang. Baik dalam hal penentuan dan penyusunan langkah-langkah tertentu yang dinilai strategis sebagai upaya pembaruan terhadap regulasi yang telah ada sebelumnya. Tak ubahnya sebagaimana langkah awal dalam proses koordinasi terhadap para aktivis gender lintas lini. Proses terjadinya pembaruan regulasi terkait hukum keluarga yang dinilai cukup fenomenal ini tak dapat terlepas dari adanya sumbangsih besar, baik dalam hal pemikiran, tenaga, politik, dan lainnya yang berasal dari kalangan koalisi aktivis perempuan yang berada di negara Maroko. $^{35}$

Selanjutnya, setelah langkah pertama telah dapat tercapai dilanjutkan dengan langkah kedua berupa proses perumusan terhadap model regulasi negara yang hendak dicapai. Baik dari segi struktural ataupun substansi pembaruan yang hendak dicapai. Proses ini cukup memakan banyak waktu, sebab ada banyak pihak dan kepentingan yang harus dapat disinergikan.

\footnotetext{
34 Komarudin, "Hukum Keluarga Di Tunisia...", 196.

35 Usman Musthafa, "Pembaharuan Hukum Keluarga Di Maroko." Syaksia: Jurnal Hukum Perdata Islam, Vol. 20 No. 1 (2020): 56, https://doi.org/10.37035/syakhsia.v20i1.1984.
}

Langkah untuk melihat kepentingan secara adil dan setara melalui bentuk perlindungan hukum terhadap Hak Asasi Manusia juga CEDAW, serta langkah menuju tercapainya argumen yang bersifat Teologis maupun non-Teologis dari berbagai kalangan terus dilakukakan. Ini dapat dikatakan termasuk dalam langkah ketiga, yang langkah keempatnya adalah proses pendampingan terhadap pihak-pihak yang memiliki kepentingan sebagai pemangku kebijakan publik, agar semua upaya yang telah dilakukan nantinya dapat tercapai. $^{36}$

Upaya terhadap perumusan pembaruan regulasi hukum keluarga ini telah disampaikan kepada pihak-pihak terkait yang memiliki kewenangan sebagai pihak pemangku kepentingan publik seperti, para Dewan Perwakilan Rakyat sebagai pihak yang berwenang untuk membuat Undang-Undang, Partai Politik yang ada di negara ini, serta utamanya Pemerintah sebagai lembaga Eksekutif.

Upaya yang kelima, adalah dengan membentuk opini-opini publik dalam suatu masyarakat. Hal ini dilakukan agar mereka dapat memahami serta berperan aktif sebagai pihak yang turut serta membela, memerjuangkan hak dan kepentingannya sebagai warga negara. Tak ubahnya sebuah aksi demonstrasi di jalanan, maupun dengan memanfaatkan kecanggihan serta kemajuan teknologi informasi. Tanpa sinergi yang kuat dan baik, rasanya semua rencana yang telah dirumuskan sebagaimana di awal tadi akan sulit untuk terealisasi. ${ }^{37}$

Suksesi pembaruan hukum keluarga dengan lahirnya "Mudawanah al-Usrah" di Maroko tentu juga tidak dapat dinafikkan atas peran seorang sultan yang begitu luar biasa di dalamnya yakni, Sultan Muhammad al-Malik as-Sa'id sebagai pemimpin negara

\footnotetext{
${ }^{36}$ Latief, "Pembaharuan Hukum Keluarga...", 199.

37 Hudafi, "Pembentukan Keluarga Sakinah Mawaddah Warahmah Menurut Undang - Undang Nomor 1 Tahun 1974 Dan Kompilasi Hukum Islam," Al Hurriyah: Jurnal Hukum Islam Vol. 5 No. 2 (2020): 175 , https://doi.org/10.30983/alhurriyah.v5i2.3647.
} 
juga pemangku kebijakan publik. Selain sebagai seorang pemimpin, bahwa yang perlu untuk diketahui adalah peran beliau sebagai seorang ulama' dan memiliki pengaruh yang besar dalam bidang keagamaan. ${ }^{38}$

Proses pembaruan regulasi terkait dengan hukum keluarga ini salah satunya dipicu oleh keinginan adanya sebuah kesetaraan gender. Artinya, kedudukan seorang suami-isteri dapat berjalan secara seimbang baik dalam lingkup keluarga ataupun masyarakat. Proses inipun juga memakan waktu yang cukup panjang hingga pada akhirnya mendapatkan suatu respon yang positif dari Sultan Muhammad alMalik as-Sa'id.

Adanya usulan draft pembaruan yang salah satunya digagas oleh para aktivis gender ini nyatanya sampai di telinga sang Raja. Kemudian Sultan mengutus serta membentuk sebuah "Komisi Khusus" yang bertugas untuk mengkaji isi dan materi pembaruan hukum keluarga yang telah disampaikan. Tak kurang dari 3 tahun, proses musyawarah serta penyusunan dan pembentukan regulasi baru dilakukakan dengan selalu melibatkan para aktivis gender tersebut. Hingga pada akhirnya di kisaran tahun 2004 draft tersebut disetujui dan disahkan menjadi "Mudawanah alUsrah".

Berbagai proses perjuangan yang tidak kalah penting dengan hasil akhirnya. Dengan ditetapkannya sebuah regulasi terkait dengan Hukum Keluarga baru yang telah mengakomodasi kepentingan perempuan dalam setiap prosesnya, serta mengindikasikan bahwa keadilan serta kesetaraan gender di negara ini juga diakui dan dijunjung tinggi keberadaannya.

Bentuk-bentuk perlawanan serta penolakan yang dilakukan dari beberapa pihak yang tidak sejalan dengan isi pembaruan, utamanya yang berasal dari kalangan "Muslim Konservatif". Akan tetapi, sebagai seorang raja yang memiliki kewenanangan serta tanggung jawab yang

${ }^{38}$ Khoiruddin Nasution, "Metode Pembaruan Hukum Keluarga...", 337. senantiasa melekat, beliau tidak hanya tinggal diam serta dengan tegasnya menghadapi proses penolakan yang datang dengan silih berganti tersebut. Hingga pada akhirnya, semua dapat dimusyawarahkan dengan baik dan tidak sedikit kalangan yang sebelumnya melakukan proses penolakan yang kemudian juga turut serta memberikan persetujuan terhadap isi pembaruan hukum keluarga itu. ${ }^{39}$

Keterpaduan antara aspek sosial, agama, budaya, politik, serta beberapa bidang dasar lainnya, dinilai cukup memberikan sumbangsih yang positif atas tercapai sebuah keberhasilan yang begitu luar biasa terhadap proses pembaruan regulasi hukum keluarga yang ada di negara Maroko. Kesadaran serta turut sertanya setiap lini-masyarakat dalam proses pembaruan ini, menjadi sebuah kekuatan tersendiri atas tercapainya kesepakatan hingga proses pengesahan terhadap isi kebijakan. Dinamika sosial yang senantiasa berubah setiap waktunya, tidak menutup kemungkinan apabila keberadaan seorang wanita juga sangat berpengaruh baik dalam lingkup domestik keluarga, maupun publik, seperti halnya keberadaan dan tugas seorang perempuan sebagai pihak pemangku kepentingan publik. ${ }^{40}$

Saat seorang perempuan telah berperan aktif dalam negara, serta mampu mengelola berbagai kepentingan yang ada di dalamnya, tidak mustahil apabila mereka pun mampu dalam mengendalikan diri, serta keluarganya sendiri. Artinya, ketika seorang perempuan yang telah pandai serta mampu mengendalikan berbagai kepentingan dasar Negara, dengan menempati berbagai jabatan-jabatan penting dalam sebuah negara, pastinya para perempuan tersebut telah mampu, bahkan sangat mampu dalam

\footnotetext{
39 Khoiruddin Nasution, "Metode Pembaruan Hukum Keluarga...", 338.

40 Cucu Solihah, "Prototype Pola Asuh Keluarga Dan Dampaknya (Suatu Kajian Pendidikan Hukum Anti Kekerasan Dalam Islam )," Res Nullius Law Journal Vol. 1 No. 1 (2019), https://doi.org/10.34010/rnlj.v1i1.2491.
} 
hal mengendalikan diri serta kepentingan mereka. ${ }^{41}$

Kesetaraan serta keadilan gender dalam sebuah keluarga dinilai sangat penting keberadaannya. Jika realita keadilan itu sendiri telah dapat tercapai sejak dari lingkup terkecil di dalam suatu keluarga, dengan tidak adanya suatu bentuk intervensi maupun stratifikasi sosial di dalamnya maka, impian tentang adanya sebuah negara yang adil akan dapat lebih mudah untuk diwujudkan menjadi suatu kenyataan.

Terkait dengan konteks sekufu di era kontemporer ini, bilamana dahulu kriteria sekufu masih terbatas pada lingkup kesetaraan dalam hal harta kekayaan, nasab, kecantikan-ketampanan seseorang, maka dalam era ini konteks sekufu lebih diartikan dengan persoalan yang lebih menyangkut urusan psikologis seseorang, seperti halnya adanya rasa sama-sama saling mencintai, mengasihi, menyayangi di antara kedua calon mempelai. Kendati, pada dasarnya urusan keagamaan seseorang tetap menjadi suatu pertimbangan utama. ${ }^{42}$

Hal ini diberlakukan mengingat, sebuah hubungan terkait dengan perkawinan merupakan sebuah hal yang dinilai sakral keberadaannya. Sekaligus antitesis terhadap konsep wali mujbir. Artinya seorang anak yang telah mencapai usia menikah, maka ia memiliki hak untuk menentukan calon pendamping hidupnya sendiri. Dengan didasari adanya rasa saling mencintai serta menyayangi di antara keduanya. Sedangkan, bentuk pemaksaan atau pengekangan terhadap seorang anak hanya akan berimbas pada kondisi psikologi sang anak menjadi tertekan atau bahkan stress.

Adanya sebuah hak kebebasan atas seorang perempuan untuk menentukan pilihannya dalam melangsungkan perkawinan di negara ini nampaknya juga

41 Cucu Solihah, "Prototype Pola Asuh Keluarga Dan Dampaknya (Suatu Kajian Pendidikan Hukum Anti Kekerasan Dalam Islam ), " Res Nullius Law Journal Vol. 1 No. 1 (2019), https://doi.org/10.34010/rnlj.v1i1.2491..

${ }^{42}$ Sulihkhodin, "Prosesi Khitbah Di Indonesia...", 394. sedikit berbanding terbalik dengan konsep wali mujbir. Mengingat keberadaan wali mujbir juga masih diakui. Akan tetapi, pada dasarnya perkawinan di negara ini dapat dilangsungkan bilamana hal itu dinilai sekufu, utamanya menyangkut sekufu dalam hal psikologi seseorang. ${ }^{43}$ Mengenai hak ijbar yang melekat pada seorang wali, dalam arti lain dapat dimaknai hak prerogatif yang melekat pada wali untuk menikahkan secara paksa anaknya, dengan tujuan utama guna menghindarkan sang anak terjerumus pada perzinahan bilamana dinilai salah di dalam pergaulan atau perbuatan fasad lainnya. ${ }^{44}$

Sebagai negara yang mayoritas penduduknya menganut madzhab Maliki, pada dasarnya konsep sekufu dimaknai dengan adanya kesetaraan dalam 2 hal yakni, sekufu dalam hal keagamaan serta kesehatan seseorang, baik itu secara fisik atau kondisi psikis seseorang. Artinya, faktor keagamaan memang tetap menjadi patokan yang penting. Selain unsur kesehatan serta rasa saling mencintai serta menyayangi di antara kedua calon mempelai ini juga memiliki kedudukan yang tidak kalah penting sebagai dasar pertimbangan seseorang dalam menentukan calon pendamping hidupnya.

Baik buruknya bahtera rumah tangga seseorang, salah satunya juga ditentukan oleh pondasi agama yang baik di antara kedua calon mempelai. Bilamana keimanan, ketaqwaan mereka dinilai baik, jika sewaktu-waktu dalam berlayarnya sebuah bahtera menemui terjangan badai yang begitu kuat, maka mereka dinilai tidak akan mudah terombang-ambing, terlebih harus berujung pada sebuah perceraian. Dinamika, pergolakan, serta gejolak di dalam suatu rumah tangga pasti akan selalu saja ada, tinggal tergantung bagaimana masingmasing pasangan suami-isteri dalam menyikapi itu semua.

\footnotetext{
${ }^{43}$ Khoiruddin Nasution, "Metode Pembaruan Hukum Keluarga...", 338.

${ }^{44}$ Moh. Alfin Sulihkhodin, "Maqashid Syariah Perspektif Izzudin Abdi Salam," El-Faqih: Jurnal Pemikiran dan Hukum Islam 7.1 (2021): 1-18, https://doi.org/10.29062/faqih.v7i1.197.
} 
Namun, sekali lagi adanya sebuah pertimbangan dalam menentukan seorang calon suami/isteri dinilai penting adanya. Dengan memerhitungkan tingkat kesekufuan atas seseorang, berarti sama halnya sebagai sebuah upaya guna meminimalisir adanya ketidakcocokan, kemungkinan konflik, atau penyesalan di kemudian hari. Atas hal ini pula, regulasi di negara Maroko juga mengatur poin terkait dengan hak seorang isteri untuk dapat mengajukan gugat cerai pada suaminya apabila: 1 . Didapati seorang suami ternyata memiliki riwayat penyakit kronis dan tidak sanggup membahagiakan isteri serta anak-anak mereka. 2. Seorang suami dinilai gagal dalam memberikan dan memenuhi setiap kebutuhan melalui nafaqah yang diiberikan pada isteri dan anak-anak mereka. 3. Didapati bahwa seorang suami melakukan sebuah tindakan aniaya, atau melakukan kekerasan dalam rumah tangga. 4. Seorang suami dengan sengaja tidak memberikan nafaqah, serta meninggalkan anak serta isterinya dalam kurun waktu kurang lebih selama satu tahun lamanya.

Atas beberapa dasar alasan tersebut, maka seorang isteri dapat mengajukan gugatan perceraian di pengadilan agama setempat guna menuntut hak mereka serta anak-anaknya. Kebolehan regulasi inipun juga sejalan dengan pendapat ulama' madzhab sebagaimana halnya Imam Syafi' $i$, Maliki, serta Hanbali, dimana beberapa poin tadi dapat dibenarkan sebagai sebuah dasar atas seorang isteri dalam mengajukan keberatannya di hadapan pengadilan. ${ }^{45}$

Sedangkan dalam hal ini, Imam Hanafi berpendapat bahwasanya seorang hakim tidak mutlak dan serta-merta boleh menjatuhkan talaq begitu saja pada seseorang. Kecuali bilamana seorang suami dari wanita tersebut benar-benar mengidap penyakit impoten. Dengannya, dapat dilihat bahwa konsep keadilan serta kesetaraan gender telah cukup terlihat secara jelas dan tegas dalam pemberlakuan pembaruan

${ }^{45}$ Moh. Alfin Sulihkhodin, "Maqashid Syariah Perspektif Izzudin Abdi Salam," El-Faqih: Jurnal Pemikiran dan Hukum Islam 7.1 (2021): 13, https://doi.org/10.29062/faqih.v7i1.197.
Undang-Undang Hukum Keluarga Islam di negara Maroko ini.

\section{F. STANDAR KAFA'AH DI NEGARA PAKISTAN}

Pakistan sebagai salah satu dari sekian negara muslim yang terdapat di dunia. Pakistan merupakan sebuah negara turunan dari negara India. Tak ayal apabila regulasi serta konstitusi di negara ini pada kisaran tahun 1960an ke bawah masih mengadopsi regulasi negara induknya yakni, India, dalam permasalahan hukum keluarga, masalah perwakafan, Perwalian dan Orang yang Berada di bawah Perwalian, Pencegahan Perkawinan usia dini, Perceraian, dan beberapa masalah keperdataan lainnya. Artinya, hampir sebagian besar isi regulasi pada saat itu masih menggunakan aturan yang diberlakukan di negara India. ${ }^{46}$

Hingga akhirnya pada kisaran tahun 1961an, atas sebuah usulan serta rekomendasi dari sebuah Komisi Nasional khusus di negara ini yang menginginkan adanya sebuah pembaruan serta penyempurnaan aturan terkait dengan hukum keluarga, dimana atas dasar itu pada akhirnya diakui serta disahkannya sebuah regulasi atau lebih dikenal dengan istilah Ordinansi Hukum Keluarga Islam di negara Pakistan ini. ${ }^{47}$

Untuk kali pertama disahkannya Konstitusi Republik Islam Pakistan pada kisaran tahun 1956, dimana maklumat dari Konstitusi tersebut menegaskan bahwa "Harus dipastikan bahwa seluruh isi dan peraturan perundang-undangan yang akan diberlakukan tidak ada satupun yang pada dasarnya bertentangan dengan perintah atau syari'at agama Islam." Artinya, semua regulasi yang ada, khususnya menyangkut dengan hukum keluarga harus senantiasa ditinjau serta diperbarui agar tidak ada

\footnotetext{
${ }^{46}$ Khoiruddin Nasution, "Metode Pembaruan Hukum Keluarga...", 338.

47 Atho' Muzhdar dan Khairuddin Nasution, Hukum Keluarga di Dunia Islam Modern, (Jakarta: Ciputat Press, 2003), 90.”
} 
isinya yang bertentangan dengan ajaran Islam yang rahmatan lil 'alamiin. ${ }^{48}$

Sebagaimana dalam regulasi terkait dengan hukum keluarga di Pakistan, atau lebih dikenal dengan istilah, "The Muslim Family Laws Ordinance" terdapat beberapa poin penting yang harus diberlakukan dalam sebuah perkawinan, antara lain: 1. Pada dasarnya negara menghendaki adanya perkawinan dengan melakukan proses pencatatan, guna menghindari adanya sebuah pelanggaran atas hak seseorang, khususnya seorang perempuan. 2. Bilamana hendak melakukan perkawinan bigami ataupun poligami, maka terlebih dahulu harus mendapatkan izin secara resmi dari pihak "Majelis Arbitrase" setempat. Sekali lagi, sebagai sebuah upaya guna melindungi hak-hak seorang perempuan agar tidak mendapatkan sebuah perlakuan yang sewenang-wenang dari suami. ${ }^{49}$

Dalam poin ke-3, terkait dengan keharusan adanya sebuah pemberitahuan terkait dengan proses perceraian dengan membentuk sebuah "Majelis Arbitrase" serta adanya ketentuan perihal perdamaian pada saat terjadinya perceraian selama kurang lebih dalam hitungan 3 bulan. 4. Bilamana terdapat suatu sengketa dalam sebuah rumah tangga seseorang, maka wajib hukumnya untuk diselesaikan di Pengadilan Keluarga, atau secara lebih dikenal sebagaimana Pengadilan Agama di negara Indonesia. Dengan demikian, tidak ada pihak yang main hakim sendiri dengan mengedepankan ego dan kepentingannya masing-masing, mengingat perkara secara langsung ditangani oleh hakim yang kompeten dan berwenang. ${ }^{50}$ Serta beberapa ketentuan dasar lainnya terkait dengan hukum keluarga.

Perihal usia perkawinan, di negara Pakistan ini memperbolehkan perkawinan terjadi bilamana seorang laki-laki telah

48 J.N.D. Anderson, Hukum Islam di Dunia Modern, alih bahasa Machnun Husein, (Surabaya: Amar Press, 1990), 23.

${ }^{49}$ Khoiruddin Nasution, "Metode Pembaruan Hukum Keluarga...", 339.

${ }^{50}$ Hudafi, "Pembentukan Keluarga Sakinah...", 176. berusia 18 tahun, dan seorang perempuan telah berusia 16 tahun. Jika dibandingan dengan regulasi Perkawinan di Indonesia, usia ini masih berada di bawah ketetapan minimal usia perkawinan yakni 19 tahun sama. Akan tetapi pada prinsipnya, regulasi di Pakistan tidak menghendaki adanya perkawinan di bawah umur.

Jika didapati seorang laki-laki menikahi perempuan di bawah usia 16 tahun, maka mereka dapat dikenakan hukuman berupa penjara atau kurungan di kisaran 1 bulan lamanya. Atau dengan dikenakan denda sebesar 1000 ruphe, atau juga dapat dikenakan sanksi keduanya. Hukuman penjara sekaligus membayar denda. ${ }^{51}$

Selanjutnya berkaitan dengan konsep $k a f a$ 'ah di negara Pakistan, pada dasarnya mengingat bahwa negara ini sebagai negara muslim dengan penduduk yang mayoritas menganut madzhab Hanafi atau Sunni, maka terkait dengan konsep kesetaraan atau kesepadanan terletak pada permasalahan dasar keagamaan seseorang calon mempelai, serta faktor kesehatan, baik secara jasmani maupun rohani.

Mengenai faktor kekayaan, kendati hal ini penting sebagai salah satu kriteria kemapanan seorang calon suami atau isteri, justru dalam hal pelaksanaan perkawinan atau pesta perkawinan di negara Pakistan ini cukup dibatasi. Hal demikian boleh dilaksanakan, akan tetapi dengan beberapa catatan. Tak ubahnya pesta harus diselenggarakan secara sederhana, dan tidak boleh terlalu mewah dan menghamburkan banyak materi. ${ }^{52}$

Hal ini juga senada serta diatur dalam regulasi perkawinan di negara Pakistan. Bilamana dengan berlakunya "The Muslim Family Laws Ordinance" ini masih ada saja pihak-pihak yang melakukan sebuah pelanggaran, maka mereka dapat dikenakan sanksi tegas dari negara, baik melalui sanksi yang bersifat pidana

\footnotetext{
51 Komarudin, "Hukum Keluarga Di Tunisia...", 199.

${ }^{52}$ Hudafi, "Pembentukan Keluarga Sakinah...", 176.
} 
(kurungan, penjara), serta sanksi yang bersifat denda atau administratif.

Hal ini rasanya cukup berbanding berbeda dengan di Indonesia. Jika di Pakistan sudah cukup diatur secara rinci dan diberlakukan pula adanya sanksi, sedangkan di Indonesia masih cukup longgar. Terlebih dari diberlakukannya sebuah sanksi atau denda dalam ranah perdata atau hukum keluarga.

\section{G. MANFAAT TERHADAP HUKUM KELUARGA DI INDONESIA}

Indonesia merupakan negara yang begitu plural dimana banyak dijumpai suku, ras, agama, budaya, bahasa, yang begitu beranekaragam di dalamnya. Sebagai negara yang majemuk, adanya peraturan perundang-undangan secara khusus berkaitan dengan permasalahan keperdataan berupa adanya Kompilasi Hukum Islam serta UU tentang Perkawinan, diharapkan mampu menciptakan ketertiban dan keadilan dalam masyarakat secara luas khususnya umat Islam. ${ }^{53}$

Adanya kebudayaan, adat-istiadat yang berbeda juga turut serta mewarnai corak hukum diantara suatu masyarakat, serta wilayah di Indonesia. Belum lagi menyangkut soal kepercayaan atau keyakinan yang dianut oleh suku tertentu. Tak ubahnya mengenai permasalahan $k a f a ' a h$ atau kriteria dalam memilih seorang calon pasangan hidup.

Mereka yang menganut kebudayaan matrilineal, patrilineal, atau parental, masing-masing menempatkan standar yang berbeda. Atau mereka yang begitu menjunjung tinggi trah/keturunan, permasalahan material atau kekayaan, sebagaimana sering didengar dalam istilah Jawa, "Bibit, bobot, bebet." UU yang belum mengatur secara khusus mengenai hal semacam ini, kiranya dapat mengambil beberapa poin penting sebagaimana

${ }^{53}$ Taufiqurrohman Syahuri, Legislasi Hukum Perkawinan di Indonesia: Pro-Kontra Pembentukannya Hingga Putusan Mahkamah Konstitusi, (Jakarta: Prenadamedia Group, 2015), 167. termaktub dalam beberapa ketentuan hukum keluarga di negara muslim dunia. Tak ubahnya produk hukum keluarga di negara Pakistan, Maroko, Yordania, atau beberapa negara muslim lain.

Ketegasan negara melalui UU yang mengatur mengenai standar kafa'ah, pesta perkawinan, dan beberapa hal penting lainnya dalam pernikahan, diharapkan mampu menciptakan ketertiban dalam kehidupan bermasyarakat dan bernegara. Agar tidak tercipta sebuah kesenjangan sosial dalam suatu masyarakat di negara Indonesia. Agar tidak ada mereka yang diberatkan ketika akan melakukan akad pernikahan karena terbentur dengan biaya. Atau mereka yang sekiranya mampu dengan sesuka hatinya dapat menghamburhamburkan harta, terlebih dalam mengejar kemewahan pada saat melangsungkan pesta pernikahan.

Kebijakan demikian menurut hemat penulis bukan bermaksud untuk terlalu mencampuri urusan keperdataan seseorang, terlebih untuk mengekang. Melainkan diharapkan dapat menciptakan sebuah kemaslahatan, baik dari segi sosial kemasyarakatan, hukum, budaya, utamanya agama. Selain itu, perlu kiranya untuk menerapkan beberapa hukuman atau sanksi bilamana terdapat pihak-pihak yang melanggar aturan perundang-undangan yang telah ditetapkan.

\section{H. KESIMPULAN}

Dari pembahasan di atas maka dapat disimpulkan bahwa, ukuran kafa'ah dalam ketentuan Hukum Keluarga Islam di negara Yordania, Maroko, serta Paksitan, pada dasarnya terletak dalam hal-ikhwal tentang kesetaraan dalam bidang nasab dan agama. Utamanya dalam bidang agama, di samping bidang lainnya seperti dalam permasalahan nasab, pendidikan, kekayaan, dan beberapa aspek penting lainnya. Akan tetapi, perlu digarisbawahi standar kafa'ah dalam perkawinan di negara Yordania serta Pakistan lebih cenderung pada ketentuan Imam madzhab Hanafi, yang mana sebagai 
kriteria utama kafa'ah adalah menyangkut 5 hal dasar meliputi: keagamaan, keturunan, hurriyah, harta kekayaan kedua calon mempelai, serta tingkatan atau bidang pekerjaan dari seseorang. Sedangkan di negara Maroko adalah lebih condong pada ketentuan Imam madzhab Maliki yang menekankan pada aspek keagamaan serta kesehatan baik itu secara fisik atau kondisi psikis seseorang. Terlepas dari semua itu, masing-masing negara telah berupaya untuk melakukan proses pembaruan regulasi terkait Hukum Keluarga yang ada di masing-masing negara dengan berbagai pertimbangan dasar tersendiri.

\section{DAFTAR KEPUSTAKAAN}

Al-Shan'any. Subul al-Salam, Juz 3. Kairo: Dar Ihya' al-Turats al-Araby, 1980.

Anderson, J.N.D. Hukum Islam di Dunia Modern, alih bahasa Machnun Husein.

Surabaya: Amar Press, 1990.

Arikunto, Suharsimi. Prosedur Penelitian:

Suatu Pendekatan Penelitian. Jakarta: Rineka Cipta, 2014.

Barkatullah, Abdul Halim., dan Teguh Prasetyo. Hukum Islam Menjawab Tantangan Zaman yang Terus Berkembang. Yogyakarta: Pustaka Pelajar, 2006.

Hudafi, Hamsah. "Pembentukan Keluarga Sakinah Mawaddah Warahmah Menurut Undang - Undang Nomor 1 Tahun 1974 Dan Kompilasi Hukum Islam." Al Hurriyah: Jurnal Hukum Islam 5, no. 2 (2020). https://doi.org/10.30983/alhurriyah.v5i 2.3647 .

Komarudin, Koko. "Hakikat Keluarga Islam", Al-Ihkam: Jurnal Hukum Keluarga, Vol. 12, No. 2 (Juni 2020).

Komarudin, Komarudin. "Hukum Keluarga Di Tunisia Dan Indonesia." Kordinat: Jurnal Komunikasi Antar Perguruan Tinggi Agama Islam 18, no. 1 (2019). https://doi.org/10.15408/kordinat.v18i1 .11481 .

Latief, Muhammad Nur Hasan. "Pembaharuan Hukum Keluarga Serta Dampaknya Terhadap Pembatasan Usia Minimal Kawin Dan Peningkatan Status Wanita." Jurnal Hukum Novelty 7 , no. 2 (2016). https://doi.org/10.26555/novelty.v7i2.a 5467.

Muslim Secular Democracy. Muslim Secular Democracy, 2013. https://doi.org/10.1057/9781137282057

Muzhdar, Atho'., dan Khairuddin Nasution. Hukum Keluarga di Dunia Islam Modern. Jakarta: Ciputat Press, 2003.

Mustofa, Imam. "Ijtihad Kontemporer Sebagai Upaya Pembaruan Hukum Keluarga Di Indonesia." Al-Manahij: Jurnal Kajian Hukum Islam 7, no. 2 (1970).

https://doi.org/10.24090/mnh.v7i2.565.

Muthiah, Aulia. Hukum Islam Dinamika Seputar Hukum Keluarga. Yogyakarta: Pustaka Baru Press, 2017. Nasution, Khoiruddin. "Metode Pembaruan Hukum Keluarga Islam Kontemporer." Unisia 30, no. 66 (October 25, 2007): 329-41.

https://doi.org/10.20885/unisia.vol30.is s66.art1.

Nurhadi, Nurhadi. "Undang-Undang No. 1 Tahun 1974 Tentang Pernikahan (Perkawinan) Di Tinjau Dari Maqashid Syariah." UIR Law Review 2, no. 2 (2018).

https://doi.org/10.25299/uirlrev.2018.v ol2(02).1841.

"Pembaharuan Hukum Keluarga Di Maroko." Syaksia: Jurnal Hukum Perdata Islam 20, no. 1 (2020). https://doi.org/10.37035/syakhsia.v20i1 .1984 . 
Ridwansyah, Muhammad. "Keadilan

Gender Dalam Rancangan Qanun

Hukum Keluarga." Jurnal Hukum

Samudra Keadilan 14, no. 2 (2019).

Rofiq, Ahmad. Hukum Perdata Islam di Indonesia Edisi Revisi, Cet. 2. Jakarta:

PT. Raja Grafindo Persada, 2015.

Saebani, Beni Ahmad. Fiqih Munakahat 1. Bandung: CV Pustaka Setia, 2013.

Solihah, Cucu. "Prototype Pola Asuh Keluarga Dan Dampaknya (Suatu Kajian Pendidikan Hukum Anti Kekerasan Dalam Islam ).” Res Nullius Law Journal 1, no. 1 (2019). https://doi.org/10.34010/rnlj.v1i1.2491. Sulihkhodin, Moh. Alfin. "Maqashid Syariah Perspektif Izzudin Abdi Salam." El-Faqih: Jurnal Pemikiran dan Hukum Islam 7.1 (2021): 1-18. https://doi.org/10.29062/faqih.v7i1.197

Sulihkhodin, Mohammad Alfin. "Prosesi Khitbah Di Indonesia Perspektif Local Wisdom Dan Qaidah Fiqh.” Bilancia: Jurnal Studi Ilmu Syariah Dan Hukum 14, no. 2 (2020): 383-400. https://doi.org/10.24239/blc.v14i2.553.

Syahuri, Taufiqurrohman. Legislasi Hukum Perkawinan di Indonesia: Pro-Kontra Pembentukannya Hingga Putusan Mahkamah Konstitusi. Jakarta: Prenadamedia Group, 2015. 